\title{
Kullanılmış Kahve Telvesinin Lif Kaynağı Olarak Değerlendirilme Potansiyeli
}

\author{
Tuğçe Boğa $a^{*}$, Enes Dertli \\ 1* Maltepe Üniversitesi, Güzel Sanatlar Fakültesi, Gastronomi ve Mutfak Sanatları Bölümü, İstanbul, Türkiye (ORCID: 0000-0003-2539-4176), \\ tugceboga@maltepe.edu.tr \\ ${ }^{2}$ Yıldız Teknik Üniversitesi, Kimya-Metalurji Fakültesi, Gıda Mühendisliği Bölümü, İstanbul, Türkiye, (ORCID: 0000-0002-0421-6103), edertli@yildiz.edu.tr
}

(İlk Geliş Tarihi 5 Nisan 2021 ve Kabul Tarihi 22 Aralık 2021)

(DOI: $10.31590 /$ ejosat.909736)

ATIF/REFERENCE: Boğa, T. \& Dertli, E. (2021). Kullanılmış Kahve Telvesinin Lif Kaynağı Olarak Değerlendirilme Potansiyeli. Avrupa Bilim ve Teknoloji Dergisi, (31), 114-120.

$\ddot{O} \mathbf{z}$

Tarih boyunca insanları ustaca bir araya getiren kahve insanların severek tükettiği bir içecek olarak günümüze gelmiştir. Kahve, oldukça zahmetli birçok işlem sonucu üretilmektedir ve dünyada atık yönetimi konusunda gelişen bilinç neticesinde kahve endüstrisi atıkları da günümüzde yeniden kazanılmaya çalışılmaktadır. Bunun sonucu olarak kahve çekirdeği zarı, cascara ve kullanılmış kahve telvesi gibi yan ürünler değerlendirilmeye çalışılmakta ve bu konuda giderek artan sayıda çalışmalar yapılmaktadır. Bu çalışmada, kahve endüstrisi atığı olan kullanılmış kahve telvesinin diyet lifi olarak kullanılma potansiyeli incelenmiştir. Dünyada her gün yaklaşık 2.5 milyar fincan kahve tüketildiği ve her bir fincan kahve için ortalama $11 \mathrm{~g}$ taze kahve kullanıldı̆̆ düşünülerek her yıl yaklaşık 500 bin ton atık kahve telvesi oluştuğu düşünülmektedir. Bu kadar büyük ve değerli bir atığın tekrar değerlendirilmesi gıda endüstrisi açısından oldukça büyük bir önem arz etmektedir.

Anahtar Kelimeler: Kahve, kullanılmış kahve telvesi, diyet lifi, Arabica.

\section{Spent Coffee Grounds As A Potential Fiber Source}

\begin{abstract}
Coffee brought people together throughout history, and today, people still consume coffee willingly. Coffee production includes many laborious processes that results in the formation of some waste materials. As a result of the awareness about waste management, coffee industry wastes are now target for the recovery process around the world. Therefore, coffee byproducts such as coffee silverskin, cascara, and spent coffee grounds are tried to be recycled, and an increasing number of studies have been carried out on this subject. In this study, the potential of role of spent coffee grounds as dietary fiber was discussed. Spent coffee grounds are wastes from both the coffee industry and domestic coffee consumption. In the world, approximately 2.5 billion cups of coffee are consumed every day. For every cup of coffee, about $11 \mathrm{~g}$ of fresh coffee is used. So it is thought these numbers, around 500 thousand tons of waste coffee grounds are produced every year. Recycling such a large and valuable waste has great importance for the food industry.
\end{abstract}

Keywords: Coffee, spent coffee grounds, dietary fiber, Arabica

\footnotetext{
*Sorumlu Yazar: tugceboga@maltepe.edu.tr
} 


\section{Giriş}

O zamanki adıyla Habeşistan olarak bilinen Etiyopya'da, M.S. 700-800 yıllarında keşfedildiği düşünülen kahve, Rubiaceae (kökboyasıiller) ailesinin Coffee cinsine aittir. Arabica ve Robusta adiyla bilinen Coffea arabica L. ve Coffea canephora Pierre adlı iki kahve türü, uluslararası kahve ticareti açısından daha önemli görülmektedir. Dünyadaki kahve üretimi \%65-70 oranında Coffea arabica L. çekirdeklerinden gerçekleştirilmektedir. Bu iki türün yanı sıra ekonomik değeri olmayan $C$. liberica ve $C$. stenophyla türlerinin üretimi de yapılmaktadır ancak dünyadaki üretimin \%98'ini Arabica ve Robusta çekirdekleri karşılamaktadır (Alves ve ark., 2017; Girginol, 2018; Herrera \& Lambot, 2017).

Kahve, Ekvator'un 23 $27^{\prime}$ kuzey enlemi (yengeç dönencesi) ile $23^{\circ} 27^{\prime}$ güney enlemi (oğlak dönencesi) arasında kalan ve kahve kemeri (the coffee bean belt) olarak adlandirilan alanda yetiştirilmektedir (Asilsoy, 2021). Kahve yetiştiriciliği genellikle küçük ölçekli aile çiftliklerinde yapılıyorsa da Brezilya'nın en büyük kahve üretici eyaleti Minas Gerais'de Cerrado Mineiro adlı bölgede, büyük ölçekli kahve çiftlikleri bulunmakta ve bu çiftlikler, üretim ve verimlilik üzerine odaklanarak profesyonel olarak yönetilmektedir. Dünya kahve tedarikinin \%70'i Brezilya, Vietnam, Kolombiya ve Endonezya olmak üzere dört ülkeden sağlanmaktadır. (Vegro \& de Almeida, 2020).

Uluslararası Kahve Organizasyonu (ICO)'nun raporunda yıllara göre kahve üretiminin giderek artan bir eğilim gösterdiği görülmektedir (Anonim, 2020a). Kahve üretimi gibi tüketiminin de yıllar içinde artışı söz konusudur. Yine Uluslararası Kahve Organizasyonu 2020 yılının Kasım ayında, ülkelere göre kahve tüketim miktarı raporu yayınlamıştır. Rapora göre kahve ihraç eden ülkeler arasında en çok kahve tüketen ülkenin 21.225 bin$60 \mathrm{~kg}$ çuval ile Brezilya olduğu, kahve ithal eden ülkeler arasında ise 42.671 bin-60 kg çuval ile Avrupa Birliği ülkeleri olduğu bildirilmiştir. Raporda, dünya genelinde kahve tüketiminin 2016/2017 ve 2019/2020 dönemleri arasında \%1.8 oranında arttığı yer almaktadır. (Anonim, 2020b).

Kahve meyvesi, beş koruyucu tabakadan oluşmaktadır ve kahve çekirdeğinin elde edilmesi sırasında bu tabakalar ayrıştırılarak uzaklaştırılmaktadır. Bunlar içeriden dışarıya doğru sırasıyla şöyledir: eliptik formda iki çekirdek, kahve çekirdeği zarı, parşömen tabaka (endokarp), pulp tabaka (mezokarp), sert dış kabuk (perikarp) (Girginol, 2018).

Kahve türüne göre değişiklik göstermekle birlikte kahve çekirdeklerinin bileşiminin yaklaşık olarak yarısında polisakkaritler, \%13'ünde proteinler ve \%12'sinde ise yağlar bulunmaktadır. Bunların dışında çeşitli mineraller, kafein ve alifatik asitler bulunmaktadır (Alves ve ark., 2017).

Kahvenin içinde 1000 'den fazla kimyasal bileşen bulunmaktadır. Kahvedeki temel değişkenler; kahve bitkisinin botanik özellikleri, büyümesi ve yetiştirilmesi, lezzeti, fizyolojisi, çiğ ve kavrulmuş haldeki özellikleri olarak siralanabilir (Girginol, 2018).

Bileşiminde yüksek miktarda bulunan lif ve kafein gibi diğer bileşikler sayesinde kahvenin antioksidan kapasitesi oldukça yüksektir. Bu nedenle kalp sağlığı üzerinde olumlu etkileri bulunmaktadır. Yüksek miktarda lif almanın önemli ölçüde kalp sağlı̆̆ını olumlu etkilediği ve diyabet, obezite, hipertansiyon gibi hastalıkları engellediği bilinmektedir (Salazar-López ve ark., 2020).

Şekil 1: Kahve meyvesi kesiti (Anonim, 2021)

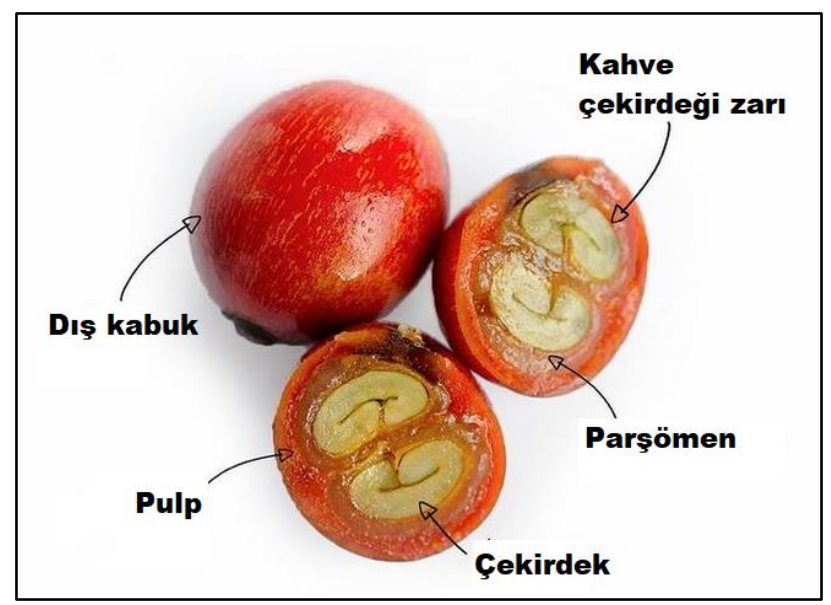

\section{Kahvenin Sağlık Üzerine Etkisi}

Tüm dünyada alkolsüz içki tüketiminin \%75'ini oluşturan kahvenin insan sağlığına etkisinin incelenmesi özellikle son yıllarda oldukça ilgi çekici bir konu haline gelmiştir. Aşırı kahve tüketimiyle ilişsili anksiyete, uykusuzluk, hipertansiyon gibi riskler nedeniyle kahvenin sik tüketilmesi tavsiye edilmemektedir. Ancak kahvenin biyolojik özellikleri ve içerdiği fitokimyasallar hakkında edinilen yeni bilgiler ile kahvenin insan sağlığına olan faydalarının olumsuz etkilerine göre daha fazla olduğu belirtilmiştir (Ciaramelli, ve ark., 2019; Higdon \& Frei, 2006).

Kahvenin sağlık üzerindeki etkisinin başlıca nedenlerinden biri antioksidan kapasitesidir. Antioksidan kapasite, kahvedeki fenolik asitler, kafein ve kavurma sırasında oluşan bazı diğer bileşiklerden ileri gelmektedir (Alves ve ark., 2017). Yapılan bir çalışmada, Arabica ve Robusta kahve çeşitleri üç farklı kavurma derecesinde ekstrakte edilmiş ve antioksidan kapasiteleri incelenmiştir. Antioksidan özellikler bakımından yeşil çekirdekler incelendiğinde Robusta'da Arabica'ya göre daha fazla kafein ve klorojenik asit bulunması nedeniyle, Robusta'nın antioksidan özelliklerinin daha fazla olduğu saptanmıştır. Kavrulmuş kahvelerde ise kavrulmayla oluşan melanoidin sebebiyle antioksidan özelliklerin benzer olduğu belirtilmiştir (Turnbull ve ark., 2017). Başka bir çalışmada ise farklı bölgelerden Arabica ve Robusta kahve çekirdeklerinde toplam fenol madde içeriği ve antioksidan kapasite karşılaştırılmıştır. Yeşil kahve çekirdeklerinin antioksidan kapasitesinin kavrulmuş kahve çekirdeklerine göre düşük olduğu belirtilmiştir (PérezBurillo ve ark., 2019).

Amerikan Kimya Derneği (American Chemical Society) raporunda, farklı kavurma derecelerindeki kahve çekirdeklerinin antioksidan bileşiklerin miktarları belirlenmiştir. Kafeoilkinik asitler (CQA), kahvedeki fenolik fraksiyonun ana bileşenleridir ve bunların sağlık üzerine olumlu etkileri olduğu bilinmektedir. Örneğin, sağlıklı gönüllü kişilerde plazmanın toplam antioksidan kapasitesinin sade kahve tüketiminden kısa bir süre sonra arttığg 
saptanmıştır. Sağlıklı gönüllülerden alınan kan örneklerinin 200 ml sütsüz ve şekersiz kahve tüketiminden 2 saat sonra plazma antioksidan kapasitesinde istatistiksel olarak anlamlı bir artış (\% 7) bildirilmiştir (Fuentes-Barría ve ark., 2018).

Bekedam ve ark. (2008), yedi farklı bölgenin Arabica çekirdeği ile dört farklı bölgenin Robusta çekirdeklerinin yeşil ve kavrulmuş haldeki toplam fenol içerikleri ve bu bileşiklerin biyoyararlanım oranları saptamıştır. Çalışmada kavrulmuş kahve çekirdeklerinde Robusta'nın Arabica'ya göre daha yüksek fenolik bileşik içeriğine sahip olduğu ancak Arabica kahve çekirdeklerinin \% biyoyararlanım oranının Robusta'ya göre daha yüksek olması nedeniyle Arabica çekirdeklerin antioksidan kapasitesinin daha yüksek olduğu bildirilmiştir. Yeşil kahve çekirdeklerinde ise fenol bileşiklerin biyoyararlanımı Arabica'ya göre Robusta'da daha yüksek bulunmuştur (Bekedam ve ark., 2008).

Birçok çalışmada kahvenin antibakteriyel, antioksidan, obezite önleyici ve anti-inflamatuar etkileri gösterilmiştir ancak kafein, klorojenik asit ve tanenler gibi bileşiklerin, ekotoksik etki gösterebileceği bildirilmiştir (Janissen \& Huynh, 2018).

\section{Kahve Üretimi}

Kahve meyvesinin kahveye işlenmesi, kahvenin tek tek toplama veya dalı sıyırma yöntemleriyle hasat edilmesiyle başlamaktadır. Kabuk ayırma ve ardından kuru veya yaş fermantasyon işleminden sonra çekirdekler boy ve yapılarına göre sınıflandırılır ve genellikle $60 \mathrm{~kg}$ 'lık çuvallarda paketlenir. Elde edilen çĭg kahve çekirdekleri, istenilen tat ve aromaların oluşması için kavrulma işlemine tabi tutulmaktadır. Kavurma işlemi tambur 1sıtmalı sistemde ve hava 1sıtmalı sistemde gerçekleşebilmektedir. Kavrulan çekirdekler yapılacak kahveye göre uygun boyutlarda öğüülür ve demlenerek veya sıcak su ekstraksiyonu ile hazır kahve üretiminde kullanılır (Martínez Sáez \& Castillo, 2019). Kahve meyvesinden bir fincan kahve içeceğine kadar olan işlem basamakları Tablo 1'de verilmiştir.

\section{Tablo 1. Kahve meyvesinden kahve içeceğine işlem basamakları}

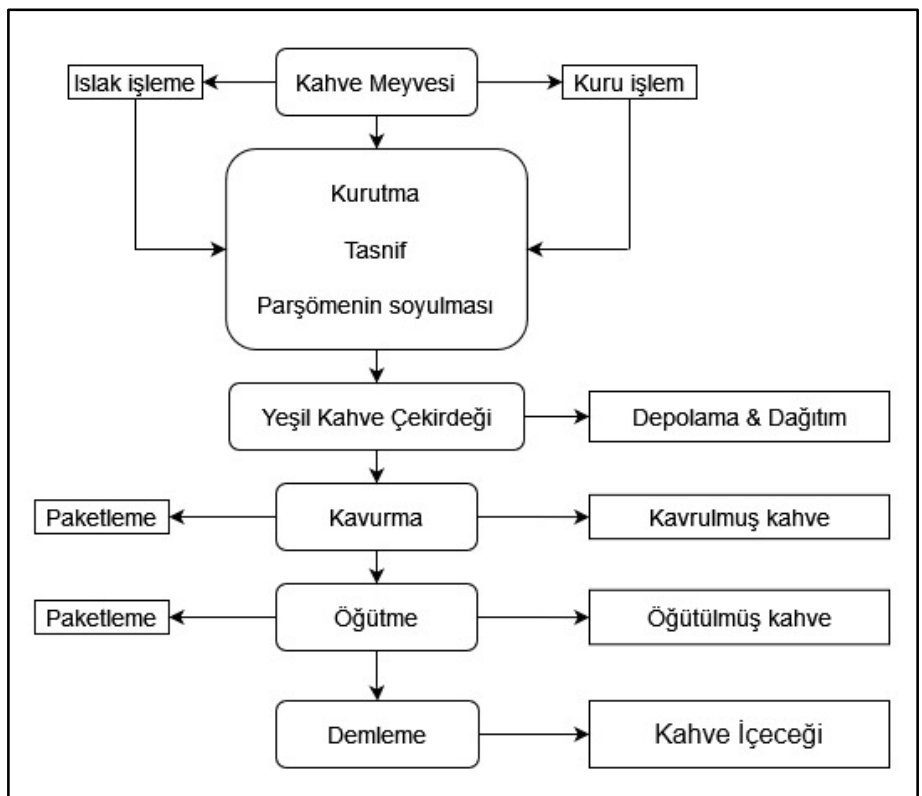

Kahve, kavurma işlemiyle 250-300 ${ }^{\circ} \mathrm{C}$ 'ye kadar çıkabilen yüksek sıcaklıklara maruz kalmaktadır. Kahvede Maillard reaksiyonu sonucu oluşabilecek akrilamidin yanı sıra, yüksek sicaklıktan kaynaklanabilecek farklı potansiyel reaksiyonlar sonucu akrilamid oluşabileceği düşünülmektedir ancak akrilamidin kahvedeki oluşum mekanizmasını açıklayacak araştırmaların sayısı kısıtlıdır (Anese ve ark., 2014). Akrilamid her ne kadar kahvelerin kavurma işlemi sırasında oluşuyor olsa da kavurma işleminin devamında akrilamidin büyük bir kısmının parçalandığ 1 düşünülmektedir. Bu nedenle az kavrulmuş kahve çekirdeklerine kıyasla çok kavrulmuş kahve çekirdeklerinde akrilamid miktarının daha düşük olabileceği belirtilmektedir (Guenther ve ark., 2007). Ayrıca kavurma işleminin düşük basınç altında gerçekleştirilmesiyle akrilamid miktarının \%50’ye kadar azaltılabileceği tespit edilmiştir (Anese ve ark., 2014).

Bir çalışmada, dört farklı hazırlama tekniği (Türk kahvesi, French Press ile yapılan kahve, filtre kahve ve espresso) ile altı adet birbirinden farklı olan kavrulmuş kahve örneklerindeki akrilamid miktarı saptanmıştır. Kahve örneklerindeki akrilamid miktarları; Türk kahvesinde $4.10 \mu \mathrm{g} / 100 \mathrm{ml}$, French Press ile yapılan kahvede $3.19 \mu \mathrm{g} / 100 \mathrm{ml}$, filtre kahvede $2.95 \mu \mathrm{g} / 100 \mathrm{ml}$ ve espressoda $2.13 \mu \mathrm{g} / 100 \mathrm{ml}$ olarak bulunmuştur. Espresso her ne kadar diğerlerine göre daha yoğun bir kahve olsa da akrilamid miktarı daha düşüktür ve bu durumun ekstraksiyon (kahve ve suyun teması) süresinin kısa olmasından kaynaklanabileceği düşünülmektedir. Çalışmada, kahve demleme yönteminin akrilamid miktarı üzerinde önemli bir etkisi bulunduğu belirtilmiştir (Michalak ve ark., 2020).

Kahvenin işlenmesi sırasında kahve meyvesinin yaklaşık \%90’1 yan ürün veya tarımsal atık olarak uzaklaştırılmaktadır ancak kahve meyvesinde sağlığ olumlu etkileyen fitokimyasallar ve besin maddeleri bulunmaktadır. Kahve endüstrisinin besince zengin yan ürünlerinin, gıda endüstrisinde potansiyel olarak fonksiyonel bileşenler olabileceği düşünülmektedir. Ayrıca atık değerlendirme konusundaki bilinç arttıkça kullanılmış kahve telvesi veya kahve çekirdeği zarı gibi kahve endüstrisinin yan ürünlerinin sağlık üzerindeki etkileriyle ilgili çalışmalar yapılmıştır (Vázquez-Sánchez ve ark., 2018; Salazar-López ve ark., 2020; Gemechu, 2020).

\section{Kahve Üretiminin Yan Ürünleri}

Kahveler toplandıktan sonra veya kavurma işlemi ve kahve tüketimi sonucunda olgunlaşmamış kahve çekirdekleri, kahve meyvesinin çeşitli kabuk katmanları ve kullanılmış kahve telvesi (KKT) gibi çeşitli yan ürünler oluşmaktadır. Kahve çekirdeğini saran pulp, müsilaj ve parşömen tabakası kuru ağırlık bazında meyvenin \%12'sini oluşturmaktadır. Bu tabakada proteinler (\%8-11), karbonhidratlar (\%58-85), yağlar (\%0.5-3), mineraller (\%3-7), indirgen şekerler (\%14), kafein ( \%1) ve tanenler ( \%5) bulunmaktadır (Alves ve ark., 2017).

Kahve çekirdeği zarı, kahve çekirdeğiyle direkt temas eden ince bir tabakadır ve kavurma işlemi ile çekirdekten ayrılabilmektedir. Her 120 ton kavrulmuş kahveden 1 ton kahve çekirdeği zarı üretilmektedir ve kahve tüketiminin giderek arttığı düşünüldüğünde kahve çekirdeği zarı, değerlendirilmek üzere büyük bir potansiyel sunmaktadır. Kahve çekirdeği zarı, protein ve diyet lifi (özellikle de çözünür diyet lifi) açısından zengin bir üründür. Ayrıca kavurma sırasında Maillard reaksiyonları sonucu oluşan melanoidinler ve fenolik bileşikler nedeniyle antiokasidan aktivite gösteren bu yan ürünün, gıda endüstrisinde 
fonksiyonel bir bileşen olarak kullanılmasına dair çalışmalar yapılmaktadır (Ballesteros ve ark., 2014; Costa ve ark., 2014).

Müslümanlar, 1100 yıl önce kahve tüccarlarının Kızıldeniz'den Arabistan'a getirdiği kahve meyvesinden fermente bir içecek yapmış ve bu içeceğe qishr adını vermişlerdir. Qishr, günümüzde baharatlı kahve kabukları, zencefil ve tarçından yapılan, demleme bir içecek olarak bilinmektedir ve Yemen'de kahveden daha fazla tüketilmektedir. Bundan 10 yıl önce, El Salvador'da kahve yetiştiren Aida Batlle isimli çiftçi ise kahve meyvesinin kurutulmasıyla yapılan bu içeceğe, İspanyolca kabuk anlamına gelen cascara kelimesinden yola çıkarak “cascara çayı” adını vermiştir. Cascarayı kurutup ögüterek ince pul halinde ve çay gibi bir demleme poşeti içinde hazırlayan Aida Batlle, cascaranın meyvemsi bir tadı olduğunu belirtmektedir (Castillo ve ark., 2017). Yapılan bir çalışmada, glütensiz ekmek formülasyonuna cascara eklenerek yapilan ekmeklerin fizikokimyasal, besinsel ve duyusal özelikleri incelenmiştir. Çalışmada, ekmeklere $\% 3$ ve $\% 4.5$ oranlarında cascara eklenmiştir ve cascara eklenmiş ekmeklerde daha düşük kabuk sertliği ve daha yüksek kabuk elastikiyeti görülmüştür. Diyet lifçe zengin ve protein oranı yüksek yeni ekmeklerin duyusal özelliklerinin pozitif etkilendiği ve raf ömürlerinin kontrol ekmeklerine göre daha yüksek olduğu saptanmıştır (Rios ve ark., 2020).

Kurutulmuş kahve meyvesi kabuğu Batılı toplumlarda ilgi çekmeye başlamış ve Bai Brand ve KonaRed adlı iki firma bu ürünle ticari olarak içecekler üretmektedir. Bai, içeceklerinde kullandığı kuru meyve kabuğunu, içerdiği antioksidan bileşikler ve kafein nedeniyle "süper meyve özü" olarak adlandırmaktadır. KonaRed ise kahve meyvesi kabuğunu kullanarak bir meyve suyu üretmektedir. Bu meyve suyunun, kahve meyvesindeki çeşitli besin ögeleri ile birlikte klorojenik asit, kinik asit ve ferulik asit gibi polifenolleri içerdiği belirtilmektedir (https://www.konared.com/; https://www.drinkbai.com/).

Kullanılmış kahve çekirdeği telvesi (KKT) ise hem evlerdeki kahve tüketimi sonucunda hem de endüstriyel olarak, hazır (instant - granül) kahve üretimi için gerçekleştirilen ekstraksiyon işlemi sonucunda oluşan bir yan üründür. Ballestros ve ark. (2014), Arabica ve Robusta kahve çekirdekleri karışımından elde edilen kullanılmış kahve telvelerinin besinsel içeriklerini analiz etmiş ve telvedeki kül içeriğinin \%1.3 oranında olduğu ve baskın elementin potasyum olduğunu saptamıştır (Ballesteros ve ark., 2014). KKT direkt olarak ekmek, kurabiye, kahvaltılık gevrekler gibi pastacılık ve şekerleme ürünlerinde kullanılabilmektedir. KKT'nin hipokalorik tatlandırıcı (stevia) ve çözünür lif (FOS) gibi yenilikçi bileşenlerle değişen oranlarda kullanıldığı formülasyonlar geliştirilmiş ve yaş bazda \%4 oranında KKT'nin kurabiye gibi katı gıda ürünlerinde gıda hazırlama yöntemini ve ürünün son kalite özelliklerini etkilemeden kullanılabileceği belirtilmiştir. Geliştirilen yeni kurabiyede, akrilamid, hidroksimetilfurfural ve glikasyon son ürünleri gibi Maillard reaksiyon ürünlerinin miktarının düşük olduğu, bu nedenle kısıtlı enerji alımı olan ve/veya diğer özel gereksinimleri olan kişiler tarafından tüketilebileceği belirtilmiştir (Castillo ve ark., 2017).

Kahve çekirdeği zarında ve kullanılmış kahve telvesinde, meyvenin etli kısmı ve kabuğuna göre daha fazla diyet lifi olduğu bilinmektedir. Ayrıca yüksek diyet lif içeriği yüksek su tutuma kapasitesi demek olduğundan, kahve çekirdeklerinin gübre uygulamalarının da faydalı olabileceği düşünülmektedir (Janissen \& Huynh, 2018).
Bir çalışmada, çiğ kahve çekirdek kabuğu (parchment), çekirdek mezokarpı (husk, pulp) ve Arabica kahve çekirdeği zarı (silverskin) toksisiteleri farelerde incelenmiş ve $2000 \mathrm{~g} / \mathrm{kg}$ vücut ağırlığı akut dozun belirli bir toksik etkiye sebep olmadığı görülmüştür. Kahve endüstrisi yan atıklarının güvenli ve sağlığa faydalı gıda bileşenleri olarak kullanılabileceği belirtilmiştir (Iriondo-DeHond ve ark., 2019).

Kahve atıklarının içecek endüstrisinde kullanımının nadir olduğu görülmektedir. Yapılan bir çalışmada, kahve çekirdeği zarı ekstraktının (CSE) in vitro ortamda pankreatik lipaz enzimi aktivitesini önemli ölçüde engellediği saptanmıştır ve CSE içeceklerinin yağ birikmesini engelleyebileceği düşünülmektedir (Martínez Sáez \& Castillo, 2019).

\section{Kullanılmış Kahve Telvesi (KKT)}

Yaklaşık 1 ton yeşil kahveden $650 \mathrm{~kg}$ atık kahve telvesi oluşmaktadır ve bu miktar yıllık 6 milyon ton civarındadır. İçinde bulunan lif, aminoasitler, polifenoller, doymuş yağ asitleri gibi bileşenler nedeniyle atık kahve telvesi son yıllarda oldukça dikkat çekmektedir. Çok miktarda diyet lifi içeren KKT'de \%54 oranında çözünmeyen diyet lifi ve yaklaşık \% 6 oranında dirençli nişasta bulunmaktadır. Kavurma işlemi sonrasında kahve çekirdeği, melanoidin, fenolik bileşikler ve diyet lifi açısından oldukça zengindir (Salazar-López ve ark., 2020).

Kullanılmış kahve telvesi direkt olarak doğal diyet lifi kaynağı olarak kullanılabilmektedir. Ancak ohmik 1sıtma, alkalin hidrojen peroksit muamelesi ve otohidroliz gibi farklı işlemler kullanılarak ham maddeden de çıkarılabilir. Kahve liflerinin antioksidan aktivitesi bu işlemlerle muameleden sonra da devam edebilmektedir. KKT'nin bağırsak fermantasyonu ile oluşan metabolitler, nitrik oksit üretimini ve inflamatuar aracı olan bazı sitokinlerin üretimini engelleyerek güçlü bir anti-inflamatuvar etki göstermektedir. Ayrıca kahve diyet liflerinin tokluk hormonu, serotonin ve glukagon benzeri peptid-1 (GLP-1) salınımını uyardığı saptanmıştır. Ek olarak, KKT’lerden otohidroliz yoluyla ekstrakte edilen antioksidan polisakkaritlerin, prebiyotikler gibi diğer biyoaktif gida bileşenlerinin enkapsülasyonunda kullanılabileceği belirtilmiştir (Ballesteros ve ark., 2017).

Diyet lifi yüksek ürünler, $\alpha$-glikozidaz enzimini inhibe ederek glisemik cevabı modüle etmektedir. Kullanılmış kahve çekirdeklerinin antioksidan diyet liflerinde (KKTAL) bulunan kateşin, gallik asit, kafeik asit gibi bileşenlerin, $\alpha$-glikozidaz enziminin aktivitesini azalttığı bilinmektedir. KKTAL'nin antidiyabetik potansiyelini inceleyen bir çalışmada, KKTAL ile zenginleştirilmiş bisküvilerin biyoyararlanılırlğı in vitro modelde incelenmiştir. Geleneksel bisküvinin yanında porsiyon başına $3 \mathrm{~g}$ ve $5 \mathrm{~g}$ KKTAL katkılı bisküviler hazırlanmıştır. $30 \mathrm{~g}$ porsiyon başına 5 g KKTAL ile zenginleştirilmiş bisküvilerin, geleneksel bisküvi ile benzer fenolik madde içeriği ve antioksidan kapasite düzeyine sahip olduğu; ancak KKTAL katkılı bisküvilerin geleneksel reçeteye göre $\% 12$ daha fazla protein içerdiği ve $\% 40$ daha fazla $\alpha$-glikozidaz inhibisyonu aktivitesi olduğu görülmüştür. Ayrıca bu örneğin \%7 daha düşük enerji içeriğine sahip olduğu ve Maillard reaksiyon ürünlerinden fruktozaminin \%89 daha yüksek, toplam ileri glikasyon son ürün (AGEs) içeriğinin ise \%74 daha düşük olduğu görülmüştür. Örnekler arasında $5 \mathrm{~g}$ KKTAL içeren bisküvi örneğinin $\alpha$-glikozidaz enzimini en çok inhibe eden örnek olduğu, bunun sebebinin ise 
kateşin ve askorbik asit biyoyararlanımına bağlı olduğu saptanmıştır (Vázquez-Sánchez ve ark., 2018).

Antioksidan aktivite ve lif kompleksi arasındaki sinerji, bir diyet lifinin tek başına sağladığından daha fazla etki göstermektedir. Demlenmiş kahvede çözünür diyet lifi miktarı $0.75 \mathrm{~g} / 100$ ml'ye kadar çıkabilmektedir. Antioksidan diyet lifi içeriği yüksek olan kahvenin toplam lif içeriğinin \%16'sını oluşturan çözünmeyen lifler oluşturmaktadır. Atık kahve telvesi ise toplamda $\% 43$ oranında lif içermektedir ve bunun $\% 8$ 'i çözünmeyen diyet lifidir. Bu nedenle, KKT'den elde edilen diyet lifi, potansiyel bir antioksidan diyet lifi olarak kategorize edilebilir (Simões ve ark., 2013).

Gıda endüstrisinin yan atıklarından kullanılmış kahve telvesi ve peynir altı suyundan besleyici özellikleri zengin yeni bir gıda bileşeni oluşabileceği düşünülen bir çalışmada, belli miktardaki peynir altı suyuna değişen oranlarda kullanılmış kahve telvesi eklenmiş ve karışım sprey kurutucuda kurutulmuştur. Daha sonra klorojenik asit, HMF, furfural ve yararlanılabilir lizin miktarları belirlenmiştir. Oluşan yeni bileşenin yüksek miktarda polifenol, klorojenik asit ve lizin içerdiği, ayrıca mikrobiyolojik olarak dayanıklı bir ürün oluştuğu saptanmıştır. Gıda endüstrisi atıkları olan bu iki ürün kombinasyonunun şekerleme, içecek, süt ve süt ürünleri gibi ürünlerin reçetelerinde kullanılabileceği belirtilmiştir (Osorio-Arias ve ark., 2020).

Muffin kek formülasyonuna toplam un miktarının \%15'i ve \%30'u kadar kullanılmış espresso telvesi (KET) eklenmiş ve tekstürel, duyusal, kimyasal özellikleri incelenmiştir. KET eklenmiş muffinlerin hacimleri değişmemekle birlikte mikroyapısının önemli ölçüde değiştiği, toplam fenolik bileşen miktarının dört kata kadar artabildiği, yüksek diyet lifi içeren bir ürün haline geldiği ve duyusal olarak kabul edilebilir düzeylerde olduğu belirtilmiştir. Ayrıca araştırmacılar, yaklaşık $40 \mathrm{~g}$ olan bir muffin yendiğinde günlük lif ihtiyacının \%12-20 oranında alınabileceğini belirtmiştir (Severini ve ark., 2020)

Sağlıklı kilodaki beş kadın ve beş erkekle yürütülen bir çalışmada, kullanılmış kahve telvesi, fruktooligosakkarit eklenmiş KKT (KKT-FOS) ve KKT'nin antioksidan diyet lifi (KKTAL) katkılı bisküvilerin tüketilmesi sonucu bireylerdeki tokluk seviyesi, enerji alımı ve gastrointestinal tolerans değerleri incelenmiştir. KKTAL katkılı bisküvilerin tokluk algısını önemli derecede arttırdığı, standart bisküviye kıyasla kişilerin yeme isteğini azaltarak enerji alımını etkilediği saptanmıştır. Ayrıca KKTAL'nin midenin boşalmasını yavaşlattığg ve dolayısıyla vücut ağırlığının korunmasında yardımcı olduğu; ayrıca karbonhidrat sindirimini yavaşlatarak yemek sonrası kan şekeri artışını düşürdüğü ve Tip-2 diyabet riskini azalttığı belirtilmiştir (Campos-Vega ve ark., 2020).

Doğal prebiyotikler birçok meyve ve sebzede bulunmakta ve süt ürünleri, firıncılık endüstrilerindeki uygulamalarda duyusal özellikleri arttırmaktadır. Kavrulmuş ve kavrulmamış yeşil kahve çekirdekleri kullanılarak oluşturulan prebiyotik oligosakkaritlerle zenginleştirilmiş kurabiyelerde yapılan bir çalışmada, \%10 ve \%12 oranında kullanılmış yeşil kahve telvesi kullanılan kurabiyelerin besleyici değerinin ve antioksidan aktivitelerin arttığı görülmüştür. Ayrıca bu kurabiyelerin daha yumuşak ve renk açısından daha iyi olduğu saptanmıştır (Desai ve ark., 2020)

Tablo 2. Kullanılmış kahve telvesi ile zenginleştirilen ürünlerde gelişen özellikler

\begin{tabular}{|c|c|c|c|}
\hline Kahve yan ürünü & Yeni ürün & Gelişen özellik & Kaynak \\
\hline $\begin{array}{l}\text { Kullanılmış Kahve } \\
\text { Telvesi (KKT) }\end{array}$ & $\begin{array}{l}\text { Kahve aromalı } \\
\text { içecek }\end{array}$ & -Kahveye ait aroma ve lezzetin yeterli düzeyde bulunması & Sampaio et al., 2013 \\
\hline $\begin{array}{l}\text { Kullanılmış Kahve } \\
\text { Telvesinin } \\
\text { Antioksidan Diyet } \\
\text { Lifi (KKTAL) }\end{array}$ & Bisküvi & $\begin{array}{l}5 \mathrm{~g} \text { KKTAL katkılı bisküvilerde; } \\
-\% 12 \text { daha fazla protein içeriği } \\
-\% 7 \text { daha düşük enerji içeriği } \\
\text { - } \alpha \text {-glikozidaz enzimi inhibisyonu } \\
\text {-Antidiyabetik ürün potansiyeli }\end{array}$ & $\begin{array}{l}\text { Vázquez-Sánchez ve ark., } \\
2018\end{array}$ \\
\hline $\begin{array}{l}\text { Kullanılmış Kahve } \\
\text { Telvesi (KKT) }\end{array}$ & Bisküvi & $\begin{array}{l}\text {-Tokluk algısında artış } \\
\text {-Diyet lifi yüksek ürün } \\
\text {-Tip-2 diyabet riskinde azalma }\end{array}$ & Campos-Vega ve ark., 2020 \\
\hline $\begin{array}{c}\text { Kullanılmış Yeşil } \\
\text { Kahve Telvesi }\end{array}$ & Kurabiye & $\begin{array}{l}\text {-Antioksidan aktivitede artış } \\
\text {-Besleyici değerde artış } \\
\text {-Duyusal özelliklerde olumlu değişim }\end{array}$ & Desai ve ark., 2020 \\
\hline $\begin{array}{l}\text { Kullanılmış Kahve } \\
\text { Telvesi (KKT) }\end{array}$ & - & -Tahıllarla benzer fitosterol içeriği & $\begin{array}{l}\text { kamgang Nzekoue ve ark., } \\
2020\end{array}$ \\
\hline $\begin{array}{l}\text { Kullanılmış Kahve } \\
\text { Telvesi (KKT) }\end{array}$ & $\mathrm{KKT}+\mathrm{PAS}^{*}$ & -Yüksek antioksidan bileşen içeriği & Osorio-Arias ve ark., 2020 \\
\hline $\begin{array}{l}\text { Kullanılmış Espresso } \\
\text { Telvesi (KET) }\end{array}$ & Muffin kek & $\begin{array}{l}\text {-Toplam fenolik bileşen içeriğinde } 4 \text { kat artış } \\
-40 \mathrm{~g} \text { muffin ile } \% 12-20 \text { günlük lif ihtiyacının karşılanması }\end{array}$ & Severini ve ark., 2020 \\
\hline
\end{tabular}

*PAS: Peynir altı suyu

Kullanılmış kahve telvesinin sıklıkla bisküvi ve kurabiye formülasyonlarında kullanılmasının nedeni, KKT'nin e-ISSN: 2148-2683 bisküvilerin rengini geliştirmesi ve istenen tipik altın rengini sağlayabilmesidir. Rafine şekersiz ürünlerin enzimatik olmayan 118 
esmerleşme reaksiyonlarının kısıtlı olduğu bilinmektedir. Ancak stevia ve kahve çekirdeği zarı ekstraktı (KZE) içeren bisküvilerin renginin, şeker içeren bisküvilere kıyasla önemli bir farklılık göstermediği saptanmış ve bu durum, KZE'nin doğal renklendirici olarak kullanılabileceğini göstermektedir. Ayrıca glütensiz olan kahve diyet liflerinin, glütensiz un üretimi ve yapay tatlandırıcı üretiminde kullanılabileceği ve böylece diyabetik veya fazla kilolu kişilerin besin ihtiyaçlarını karşılamada yardımcı olabileceği düşünülmektedir (MartinezSaez ve ark., 2017; Martínez Sáez \& Castillo, 2019)

Fazla kilolu ve sağlıklı kadın donörlerin bağırsağındaki sindirilmemiş atık kahve telvesi (KKT) fraksiyonlarının incelendiği bir çalışmada, kolon fermantasyonu sırasında fazla kilolu ve sağlıklı bireylere ait mikrobiyotalar arasında, sindirilmemiş KKT fraksiyonlarındaki polifenolik bileşik metabolizmasının ve biyoerişilebilirliğinin farklılık gösterdiği ve böylelikle bunların HT-29 hücrelerine karşı sitotoksisitesiyi modüle ettiği gösterilmiştir. Normal kilolu insandaki mikrobiyota tarafindan KKT'nin kolonik fermantasyonu ile üretilen metabolitler, esas olarak katalaz ve lipid peroksidasyonu yoluyla oksidatif stresi azaltarak apoptozu tetiklemektedir (Hernández-Arriaga ve ark., 2017).

12 ülkeden 14 farklı kullanılmış kahve telvesi örneğiyle yapılan bir çalışmada, kahve telvesinin ticari fitosterol kaynağ olarak kullanılabilme potansiyeli incelenmiştir ve KKT örneklerinin fitosterol profili çıkarılmıştır. Çalışmaya göre KKT'deki fitosterol miktarının tahıllardaki kadar yüksek olduğu ve fitosterolün artan talebini karşılayabileceği düşünülmektedir (kamgang Nzekoue ve ark., 2020).

Bir çalışmada, KKT diyet liflerinin bağırsak metabolizması sonucu oluşturduğu kısa zincirli yağ asitlerinin güçlü bir antiinflamatuar etkiye sahip olduğu ve nitrik asit ile bazı sitokinlerin oluşumunu baskıladığı saptanmıştır. KKT'nin kronik bağırsak hastalıklarıyla mücadelede etkili olabileceği belirtilmiştir (López-Barrera ve ark., 2016).

Son olarak KKT'nin kafeinle zenginleştirilmiş bir biyoaktif ekstrakt elde edilmesinde hammadde olarak kullanılabileceği önerilmektedir. KKT'nin Staphylococcus aureus ve Escherichia coli üzerinde antimikrobiyal etkisi olduğu ve bu etkinin KKT yapısında bulunan melanoidinlerden kaynaklandığ düşünülmektedir. KKT'den elde edilen kahve melanoidinlerinin antimikrobiyal etkisinin normal melanoidinlere göre 2-5 kat daha fazla olduğu saptanmıştır (Castillo et al., 2017).

Sampaio ve ark. (2013)'nın yaptığı çalışmada, KKT kullanarak kahve aromalı damıtılmış bir içecek üretmiştir. Aromatik bileşiklerin şeker eklenmiş KKT'nin sulu ekstraksiyonu ile eldesi ve etanol üretimi sonucu üretilen bu içecekte alkoller, esterler, aldehitler ve asitler dâhil toplam on yedi uçucu bileşik tanımlanmıştır. Bu bileşiklerin, üründe hoşa gidebilecek özellikleri hissettirecek konsantrasyonlarda bulunduğu; üretilen içeceğin organoleptik özelliklerinin kabul edilebilir düzeyde olduğu ve kahve kokusu, kahve tadı olan hoş bir içecek niteliği taşıdığı düşünülmektedir (Sampaio et al., 2013).

Kahve alanında yapılan çalışmalar henüz sınırlı olmakla birlikte son yıllarda sayıları giderek artmaktadır. Bu çalışmada da kahve üretimi sonucu oluşan kullanılmış kahve telvelerinin diyet lifi olarak kullanılma potansiyeli ve gida endüstrisindeki potansiyel kullanım alanları değerlendirilmiştir.

\section{Sonuç}

Tüketim miktarı oldukça yüksek olan ve kültürümüzdeki yeri çok eskilere dayanan kahvenin sağlık üzerinde çeşitli olumlu etkileri bulunmaktadır. Kahvenin yanı sıra kahve endüstrisinden oluşan yan ürünlerin tekrar değerlendirilmesi, son yıllarda hem tüketici hem de çevre bilincinin artmasıyla ve geri dönüșümün gerekliliğine çekilen dikkatlerle önemli hale gelmiş ve bu konuda çalışmalar yapılmaya başlanmıştır. Her ne kadar bu konuda belirli bir istatistiğe rastlanmasa da sayıları giderek artan kahve dükkânlarından ve ICO'nun yayınladığı Kahve Tüketim Miktarı Raporu'ndan (Anonim, 2020b) yola çıkıldığında kahve atıklarının ne kadar fazla olabileceğini tahmin etmek güç değildir. Ülkemizin ve dünyanın her yerinde her gün tüketilen çok sayıda espresso temelli kahvenin (espresso, cappucino, americano, cafe latte, vb.) atıklarını yeniden değerlendirebilmek, hem atıkların değerlendirilmesi açısından hem de geliştirilecek yeni fonksiyonel ürünlerin insan sağlığı üzerindeki potansiyel olumlu etkileri düşünüldüğünde oldukça önemli hale gelmektedir. Bu çalışmada, kullanılmış kahve telvelerinin diyet lifi potansiyeli araştırılmış ve gıda endüstrisindeki kullanım alanları belirlenmeye çalışılmıştır. İlgili literatür incelenmiş ve kullanılmış kahve telveleri ile gerçekleştirilen bisküvi uygulamalarının oldukça iyi sonuçlar verdiği, kullanılmış kahve telvelerinin glütensiz ürün geliştirilmesinde yardımcı olarak kullanılabileceği ve iyi bir diyet lifi olarak kullanılabileceği görülmüştür.

\section{Kaynakça}

Alves, R. C., Rodrigues, F., Antónia Nunes, M., Vinha, A. F., \& Oliveira, M. B. P. P. (2017). State of the art in coffee processing by-products. In: Handbook of Coffee Processing By-Products, C. M. Galanakis (Eds.), Academic Press, 1-26.

Anese, M., Nicoli, M. C., Verardo, G., Munari, M., Mirolo, G., \& Bortolomeazzi, R. (2014). Effect of vacuum roasting on acrylamide formation and reduction in coffee beans. Food Chemistry, 145, 168-172.

Anonim. (2020a). Coffee Market Report November 2020. Retrieved from http://www.ico.org/documents/cy202021/cmr-1120-e.pdf

Anonim. (2020b). World Coffee Consumption. Retrieved from http://www.ico.org/prices/new-consumption-table.pdf

Anonim. (2021). https://www.instagram.com/p/B2ZysV4IOm6/ 4.04.2021 tarihinde alınmıştır.

Asilsoy, U. (2021). Nitelikli Kahve. İstanbul: Aya Kitap.

Ballesteros, L. F., Teixeira, J. A., \& Mussatto, S. I. (2014). Chemical, functional, and structural properties of spent coffee grounds and coffee silverskin. Food and Bioprocess Technology, 7(12), 3493-3503.

Ballesteros, L. F., Teixeira, J. A., \& Mussatto, S. I. (2017). Extraction of polysaccharides by autohydrolysis of spent coffee grounds and evaluation of their antioxidant activity. Carbohydrate Polymers, 157, 258-266.

Bekedam, E. K., Loots, M. J., Schols, H. A., Van Boekel, M. A., \& Smit, G. (2008). Roasting effects on formation mechanisms of coffee brew melanoidins. J Agric Food Chem, 56(16), 7138-7145.

Campos-Vega, R., Arreguín-Campos, A., Cruz-Medrano, M. A., \& del Castillo Bilbao, M. D. (2020). Spent coffee (Coffea arabica L.) grounds promote satiety and attenuate energy intake: A pilot study. Journal of Food Biochemistry, 44(6), e13204. 
Castillo, M., Iriondo-DeHond, A., Martinez-Saez, N., Fernandez-Gomez, B., Iriondo De-Hond, M., \& Zhou, J.-R. (2017). Applications of recovered compounds in food products. In: Handbook of Coffee Processing By-Products, C. M. Galanakis (Eds.), Academic Press, 171-194

Ciaramelli, C., Palmioli, A., \& Airoldi, C. (2019). Coffee variety, origin and extraction procedure: Implications for coffee beneficial effects on human health. Food Chemistry, 278, 47-55.

Costa, A. S. G., Alves, R. C., Vinha, A. F., Barreira, S. V. P., Nunes, M. A., Cunha, L. M., \& Oliveira, M. B. P. P. (2014). Optimization of antioxidants extraction from coffee silverskin, a roasting by-product, having in view a sustainable process. Industrial Crops and Products, 53, 350357.

Desai, N. M., Mallik, B., Sakhare, S. D., \& Murthy, P. S. (2020). Prebiotic oligosaccharide enriched green coffee spent cookies and their nutritional, physicochemical and sensory properties. LWT-Food Science and Technology, 134, 109924.

Fuentes-Barría, H., Peña, M., Eguía, A., \& Wong, G. (2018). Influence of the bioactives compounds of beetroot (Beta vulgaris L) on the cardioprotective effect: A narrative review Revista Chilena de Nutrición, 45 (2), 178-182.

Gemechu, F. G. (2020). Embracing nutritional qualities, biological activities and technological properties of coffee byproducts in functional food formulation. Trends in Food Science \& Technology, 104, 235-261.

Girginol, C. (2018). Kahve-Topraktan Fincana. İstanbul: A7 Kitap.

Guenther, H., Anklam, E., Wenzl, T., \& Stadler, R. H. (2007). Acrylamide in coffee: Review of progress in analysis, formation and level reduction. Food Additives \& Contaminants, 24(1), 60-70.

Hernández-Arriaga, A. M., Oomah, B. D., \& Campos-Vega, R. (2017). Microbiota source impact in vitro metabolite colonic production and anti-proliferative effect of spent coffee grounds on human colon cancer cells (HT-29). Food Research International, 97, 191-198.

Herrera, J. C., \& Lambot, C. (2017). The Coffee Tree - Genetic Diversity and Origin. In: The Craft and Science of Coffee, B. Folmer (Eds.), Academic Press, 1-16.

Higdon, J. V., \& Frei, B. (2006). Coffee and health: a review of recent human research. Critical Reviews In Food Science And Nutrition, 46(2), 101-123.

Iriondo-DeHond, A., Garcia, N. A., Fernandez-Gomez, B., Guisantes-Batan, E., Escobar, F. V., Blanch, G. P., San Andres, M. I., Sanchez-Fortun, S., del Castillo, M. D. (2019). Validation of coffee by-products as novel food ingredients. Innovative Food Science \& Emerging Technologies, 51, 194-204.

Janissen, B., \& Huynh, T. (2018). Chemical composition and value-adding applications of coffee industry by-products: A review. Resources, Conservation and Recycling, 128, 110117.

kamgang Nzekoue, F., Khamitova, G., Angeloni, S., Sempere, A. N., Tao, J., Maggi, F., Xiao, J., Sagratini, G., Vittori, S., Caprioli, G. (2020). Spent coffee grounds: A potential commercial source of phytosterols. Food Chemistry, 126836.

López-Barrera, D. M., Vázquez-Sánchez, K., Loarca-Piña, M. G. F., \& Campos-Vega, R. (2016). Spent coffee grounds, an innovative source of colonic fermentable compounds, inhibit inflammatory mediators in vitro. Food Chemistry, 212, 282290.

Martinez-Saez, N., García, A. T., Pérez, I. D., Rebollo-Hernanz, M., Mesías, M., Morales, F. J., Martin-Cebrejas, M., del Castillo, M. D. (2017). Use of spent coffee grounds as food ingredient in bakery products. Food Chemistry, 216, 114122.

Martínez Sáez, N., \& Castillo, M. (2019). Development of sustainable novel foods and beverages based on coffee byproducts for chronic diseases. Reference Module in Food Science, Encyclopedia of Food Security and Sustainability 1, 307-315.

Michalak, J., Czarnowska-Kujawska, M., Gujska, E., Klepacka, J., \& Tońska, E. (2020). Effect of the brewing process on the acrylamide content in coffee beverages. Proceedings of the Nutrition Society, 79(OCE2), E293.

Osorio-Arias, J., Contreras-Calderón, J., Martínez-Monteagudo, S. I., \& Vega-Castro, O. (2020). Nutritional and functional properties of spent coffee ground-cheese whey powder. Journal of Food Process Engineering, e13524.

Pérez-Burillo, S., Mehta, T., Esteban-Muñoz, A., Pastoriza, S., Paliy, O., \& Rufián-Henares, J. Á. (2019). Effect of in vitro digestion-fermentation on green and roasted coffee bioactivity: The role of the gut microbiota. Food Chemistry, 279, 252-259.

Rios, M. B., Iriondo-DeHond, A., Iriondo-DeHond, M., Herrera, T., Velasco, D., Gómez-Alonso, S., Callejo, M. J., del Castillo, M. D. (2020). Effect of coffee cascara dietary fiber on the physicochemical, nutritional and sensory properties of a gluten-free bread formulation. Molecules, 25(6), 1358.

Salazar-López, N. J., López-Rodríguez, C. V., Hernández-Montoya, D.A., Campos-Vega, R. (2020). Health Benefits of Spent Coffee Grounds. In: Food Wastes and By-products, R. Campos-Vega, B.D. Oomah and H.A. Vergara-Castañeda (Eds.), 327-351

Sampaio, A., Dragone, G., Vilanova, M., Oliveira, J. M., Teixeira, J. A., \& Mussatto, S. I. (2013). Production, chemical characterization, and sensory profile of a novel spirit elaborated from spent coffee ground. LWT-Food Science and Technology, 54(2), 557-563.

Severini, C., Caporizzi, R., Fiore, A. G., Ricci, I., Onur, O. M., \& Derossi, A. (2020). Reuse of spent espresso coffee as sustainable source of fibre and antioxidants. A map on functional, microstructure and sensory effects of novel enriched muffins. LWT-Food Science and Technology, 119, 108877.

Simões, J., Nunes, F. M., Domingues, M. R., \& Coimbra, M. A. (2013). Extractability and structure of spent coffee ground polysaccharides by roasting pre-treatments. Carbohydrate Polymers, 97(1), 81-89.

Turnbull, D., Rodricks, J. V., Mariano, G. F., \& Chowdhury, F. (2017). Caffeine and cardiovascular health. Regulatory Toxicology and Pharmacology, 89, 165-185.

Vázquez-Sánchez, K., Martinez-Saez, N., Rebollo-Hernanz, M., del Castillo, M. D., Gaytán-Martínez, M., \& Campos-Vega, R. (2018). In vitro health promoting properties of antioxidant dietary fiber extracted from spent coffee (Coffee arabica L.) grounds. Food Chemistry, 261, 253-259.

Vegro, C. L. R., \& de Almeida, L. F. (2020). Global coffee market: Socio-economic and cultural dynamics. In: Coffee Consumption and Industry Strategies in Brazil, L. F. de Almeida and E. E. Spers (Eds.), Elsevier, 3-19. 